doi: 10.31140/j.vestnikib.2017.4(202).10

\title{
МИХАИЛ МИХАЙЛОВИЧ ЧАРОЧКИН
}

(21.11.1902-04.06.1976)

\author{
К.С. Зайнуллина \\ Федеральное государственное бюджетное учреждение науки \\ Институт биологии Коми научного иентра Уральского отделения РАН, Сыктывкар \\ E-mail: zainullina@ib.komisc.ru
}

\begin{abstract}
21 ноября 2017 г. исполнилось 115 лет со дня рождения Михаила Михайловича Чарочкина - видного исследователя в области интродукции плодово-ягодных и декоративных растений, большого энтузиаста зеленого строительства в Республике Коми.
\end{abstract}

Михаил Михайлович родился в 1902 г. в г. Ряжске Рязанской губернии в семье служащего. М.M. Чарочкин избрал себе одну из самых мирных профессий - в 1923 г. он поступил учиться на плодово-овощное отделение Рязанского сельскохозяйственного техникума, который окончил в 1927 г. и получил специальность техника по садоводству и овощеводству.

В 1930-1931 гг. он работал участковым агрономом Рязанского Райземотдела. Решив продолжить свое образование, Михаил Михайлович поступил в Ленинградский плодовоовощной институт (г. Пушкин). Годы учебы в институте (1931-1936 гг.)

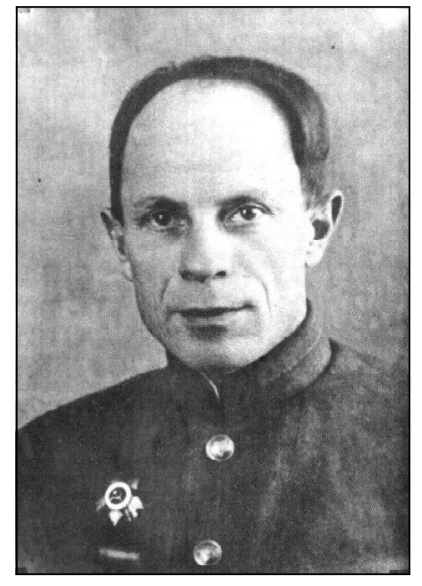

Михаил Михайлович Чарочкин

21.11.1902-04.06.1976

затем в секторе сельскохозяйственной биологии и экономики, а с 1962 г. и до выхода на пенсию (1971 г.) в лаборатории интродукции растений Института биологии Коми филиала АН СССР.

Много труда, творческой энергии и таланта M.M. Чарочкин вложил в становление ботанического сада, который создавался на территории Выльгортского плодово-ягодного питомника, и коллекционных участков кормовых, овощных и других полезных растений в соответствии с приказом № 156 по Базе АН ССCР в Коми АССР от 15 ноября 1946 г.

После возвращения в г. Сыктывкар М.М. Чарочкин продолжил свою многое дали для формирования личности М.M. Чарочкина, укрепили его желание заняться продвижением садоводства на Север, и, получив диплом, он принял решение поехать на работу в Коми ACCP. Здесь по заданию Коми Наркомзема он взялся за организацию плодово-ягодного питомника в с. Выльгорт Сыктывдинского района. $\mathrm{Pa}$ бота шла успешно, и уже в 1940 г. питомник располагал богатой коллекцией плодово-ягодных растений, включавшей 142 сорта яблонь, 146 смородины, 76 - малины, 23 - земляники, 12 крыжовника и 47 видов других плодовых культур. По итогам исследований М.М. Чарочкиным был составлен рекомендуемый ассортимент плодово-ягодных растений для республики, который утвердил Совет Министров Коми АССР. После выявления сортов, перспективных для выращивания на Севере, ученый приступил к их массовому размножению в плодово-ягодном питомнике, и уже с 1942 г. питомник обеспечивал посадочным материалом хозяйства республики. В 1941 г. началась война, и М.М. Чарочкин был призван на фронт. Он участвовал в боях на Карельском фронте, был дважды ранен. За героизм, проявленный в годы войны, М.M. Чарочкин награжден Орденом Отечественной войны II степени. После демобилизации в декабре 1945 г. Михаил Михайлович вернулся в Сыктывкар и поступил на работу в Коми базу Академии наук СССР. Сначала он работал в секторе растительных ресурсов,

научно-исследовательскую работу с плодовоягодными культурами. В эти годы он большое внимание уделял интродукции ягодных растений из местной флоры (смородина, малина, шиповник и др.). В 1950 г. М.М. Чарочкин совместно с К.А. Моисеевым опубликовал монографию «Ягодные культуры в Коми АССР». Эта работа подвела итог 14-летним исследованиям. Для республики это была первая обобщающая сводка по интродукции ягодных растений. В ней дана сравнительная оценка продуктивности перспективных сортов ягодных культур, характеристика разработанных приемов их внедрения в производство. С 1956 г. М.М. Чарочкин начал исследования по проблеме интродукции декоративных древесных и травянистых растений с целью обогащения местной культурной флоры новыми видами. Только за первое десятилетие работ были высеяны семена 1250 образцов древесных растений и 1180 травянистых многолетников. При отборе исходного материала главное внимание обращали на зимостойкость, декоративность и легкость размножения вида.

M.M. Чарочкин всегда сочетал научные исследования с практической работой по внедрению в производство новых видов ягодных и декоративных растений. Ученый проводил в ботаническом саду многочисленные экскурсии для ознакомления студентов и учащихся школ с результатами интродукции растений. Михаил Михайлович при- 


\section{ВЕСТНИК ИБ КОМИ НЦ УрО РАН 2017 № 4}

нимал самое активное участие в мероприятиях по озеленению скверов, парков, территорий возле общественных зданий и учебных заведений Сыктывкара. Многие растения, высаженные М.M. Чарочкиным, и поныне являются гордостью ботанического сада Института биологии. Среди них кедры, лиственницы, туи, сирени, яблони, дубы, ясени, ель колючая (форма голубая) в аллейных и групповых посадках.

За период научной деятельности М.М. Чарочкин опубликовал более 40 работ. Многие резуль- таты его научной работы остались не опубликованными и сохранились в виде рукописных отчетов. Научное наследие ученого послужило основой для дальнейших интродукционных исследований, проводимых в созданном им ботаническим саду Института биологии Коми филиала АН CCCP.

Скончался М.М. Чарочкин 4 июня 1976 г. Похоронен в г. Сыктывкаре.

\section{MIKHAIL MIKHAILOVICH CHAROCHKIN (21.11.1902-04.06.1976)}

\section{C.S. Zainullina}

Institute of Biology of Komi Scientific Centre of the Ural Branch of the Russian Academy of Sciences, Syktyvkar

November 21, 2017 marks the 115th anniversary of the birth of Mikhail Mikhailovich Charochkin, a prominent researcher in the field of introduction of fruit and berry plants and great enthusiasist of the green building in the Komi Republic.

He was born in 1902 in Ryazhsk town in the Ryazan Province in the official's family. M. Charochkin chose one of the most peaceful professions and in 1923 he was entered the Ryazan Agricultural technical College, fruits and vegetables department. He graduated from the College in 1927 with the diploma in the field of horticulture and vegetable growing.

In 1931, he entered the Leningrad (St. Petersburg) Fruit and Vegetable Institute (Pushkin). The years of study at the Institute (1931-1936) gave so much for the formation of Charochkin's personality and strengthened his desire to promote the gardening to the North. So, he decided to go to work in the Komi Republic. Here, M. Charochkin begun to study the introduction of ornamental trees and herbs in order to enrich the cultural flora of our region with new species. Only for the first decade, the seeds of 1250 samples of tree plants and 1180 herbaceous perennials were sown. When selecting the source material, the main attention was paid to winter hardiness, decorativeness and ease of reproduction of the species. Many of plants planted by M. Charochkin still are the pride of the Botanical Garden of the Institute of Biology: Siberian pines, larches, thujas, lilacs, apple trees, oaks, ashes, spruce (blue form) being planted in alley and group plantings.

$M$. Charochkin was very active in the activities on the greening the Syktyvkar: public gardens, parks and territories near public buildings and education institutions.

For the period of scientific activity, M. Charochkin has published more than 40 works. His scientific heritage was the basis for the further introduction researches carried out in created by him the Botanical Garden of the Institute of Biology of Komi Scientific Centre of RAS.

Перевод на английский: Ю. Дубровский 